\title{
Forage Yield of Five Grasses Under Intensive Grazing Management in the Humid Region of Puerto Rico, ${ }^{1,2}$
}

\author{
Edmundo Rivera and José Rodriguez ${ }^{3}$
}

\begin{abstract}
Three grasses on intensively managed and grazed $10 \times 10 \mathrm{~m}$ plots produced statistically similar yields of dry forage over a 3-year period expressed in $\mathrm{kg} / \mathrm{ha} / \mathrm{yr}$ as follows: Stargrass - 12,445; Coast Cross \#112,285; and Hemarthria PI 299995-13,685. Hemarthria PI 299994 produced significantly higher yields-15,370 kg/ha/yr. Cynodon plectostachyus, on the other hand, did not tolerate intensive grazing and produced only 4,695 $\mathrm{kg} / \mathrm{ha}$ during the second year. Yields of Star and Hemarthria PI 299995 were comparable to yields obtained in a large scale grazing experiment nearby, which confirmed the validity of the small experimental plot technique in determining yield potential of grazed forage grasses.
\end{abstract}

\section{INTRODUCTION}

The productivity of many of the best known tropical grasses in terms of carrying capacity and milk or meat production, has been determined in numerous grazing experiments on steep Ultisols in the humid mountain region of Puerto Rico. Caro-Costas et al. (3) determined the productivity of intensively managed Para (Brachiaria purpurascens (Raddi) Hnr.), Molasses (Melinis minutiflora Beauv), Guinea (Panicum maximum Jacq.), Pangola (Digitaria decumbens Stent), and Napier (Pennisetum purpureum Schumach) grass pastures. Pangola, Guinea and Napier grass pastures produced similar weight gains, outyielding those of Para and Molasses pastures. Caro-Costas et al. (2) found that Star grass (Cynodon nlemfuensis) pastures produced higher weight gains than did those of Pangola grass. Caro-Costas et al. (4) found that Star grass pastures produced higher weight gains than did those of Congo (Brachiaria ruziziensis), or Pangola grass.

The numerous experiments conducted in Puerto Rico to determine the productivity of Napier, Pangola, Guinea, Star, Congo and Para grasses under cutting management have been summarized by Vicente-Chandler et al. $(7,8)$. The performance of these grasses under cutting was often different from performance with grazing management.

\footnotetext{
${ }^{1}$ Manuscript submitted to Editorial Board March 1, 1979.

${ }^{2}$ Research conducted cooperatively between Agricultural Research, Science and Education Administration, USDA and the College of Agricultural Sciences, Mayagüez Campus, University of Puerto Rico, Río Piedras, P.R.

${ }^{3}$ Agronomist, Agricultural Research, Science and Education Administration, USDA, and Assistant Agronomist, Agricultural Experiment Station, College of Agricultural Sciences, Mayagüez Campus, University of Puerto Rico, respectively.
} 
Many other grasses have been introduced to Puerto Rico, yet there is little information on their productivity with grazing management under local conditions similar to those of vast areas in the humid tropics.

Determining the productivity of grasses when harvested by cutting is relatively easy, but such experiments do not provide reliable information on their performance under grazing conditions, which includes selective grazing by the cattle, trampling of the forage, soil compaction and voiding of urine and feces. On the other hand, it is very costly to evaluate large numbers of grasses when their productivity is determined in full scale grazing experiments in terms of carrying capacity and milk or meat production.

Vicente-Chandler, et al. (9) devised a low cost method for determining the performance of grasses or the effect of management systems on forages under actual grazing conditions. This system has been successfully used by Vicente-Chandler et al. (9) and Rodríguez and Silva (5) to determine the effect of grazing heights and intervals on the performance of Pangola and Star grasses, and by Rodríguez, et al (6) to compare the productivity of four grasses under grazing management. In the latter study, results obtained with this technique were comparable to those obtained in nearby large scale grazing experiments with three of these grasses.

The present study determined the production of dry forage by five tropical grasses under actual grazing conditions using the above mentioned techniques.

\section{MATERIALS AND METHODS}

The experiment was conducted over a 3-yr period (July 1, 1975-June $30,1978)$ at the Corozal Substation. Elevation is about $200 \mathrm{~m}$ and average annual temperature is about $25^{\circ} \mathrm{C}$ with seasonal variations of about $4^{\circ}$ C. The soil is Corozal clay (Aquic Tropudults), on a $25 \%$ slope.

The five grasses listed in table 1 were tested in $10 \times 10 \mathrm{~m}$ plots replicated five times in a randomized block design. A solid stand was established in each plot; the soil was limed to about pH 5.5. A 15-5-10 fertilizer was applied at the rate of 2.2 metric tons/ha/yr divided in four equal applications.

The plots, each surrounded by a barbed and chicken wire fence to prevent cattle from grazing adjacent plots, were grazed at 3- to 4-week intervals. One Holstein heifer was confined to each plot until the grass had been grazed to a height of about $15 \mathrm{~cm}$, a period of 1 to 2 days.

The forage consumed by the cattle in each plot at each grazing was determined as follows: Five pairs of $0.4 \mathrm{~m}^{2}$ sampling areas, which were representative of the forage in the plots, were located in each plot before each grazing round. The forage in one of each pair was cut to a height of 
TABLE 1.-Productivity of five grasses under grazing management in the humid region of Puerto Rico

\begin{tabular}{|c|c|c|c|c|c|}
\hline \multirow[b]{2}{*}{ Grass } & \multicolumn{4}{|c|}{ Yields of dry forage $(\mathrm{kg} / \mathrm{ha} / \mathrm{yr})$} & \multirow{2}{*}{$\begin{array}{c}\text { Nearby } \\
\text { large } \\
\text { grazing } \\
\text { experi- } \\
\text { ments }\end{array}$} \\
\hline & $1975-76$ & $1976-77$ & $1977-78$ & Average & \\
\hline Star (Cynodon nlemfuensis) & $13,145 b^{2}$ & $12,610 \mathrm{a}$ & $11,580 \mathrm{a}$ & $12,445 \mathrm{~b}$ & 13,820 \\
\hline Coast Cross \#1 ( $C$ dactylon) & $13,575 \mathrm{~b}$ & $13,420 \mathrm{a}$ & $12,860 \mathrm{a}$ & $12,285 \mathrm{~b}$ & - \\
\hline Cynodon plectostachyus & $13,970 \mathrm{~b}$ & $4,695 \mathrm{~b}$ & - & - & - \\
\hline $\begin{array}{l}\text { Greenalta (Hemarthria altis- } \\
\text { sima)-PI 299994) }\end{array}$ & $17,970 \mathrm{a}$ & $13,420 \mathrm{a}$ & $14,720 \mathrm{a}$ & $15,370 \mathrm{a}$ & - \\
\hline $\begin{array}{l}\text { Bigalta (Hemarthria altis- } \\
\text { sima-PI 299995) }\end{array}$ & $15,180 \mathrm{~b}$ & $11,800 \mathrm{a}$ & $14,080 \mathrm{a}$ & $13,685 \mathrm{~b}$ & 12,740 \\
\hline
\end{tabular}

${ }^{1}$ From Caro-Costas (1).

${ }^{2}$ Values followed by the same letter do not differ significantly at the $5 \%$ level. (Duncan's new multiple range test).

$5 \mathrm{~cm}$, dried, and weighed. These data provided an estimate of the quantity of forage available to the grazing cattle. After grazing, the forage in the remaining five sampling areas was also cut to a height of $5 \mathrm{~cm}$, dried, and weighed. These data provided an estimate of the forage remaining after grazing. The forage consumed by the grazing cattle was calculated by substracting the quantity of forage remaining on the plots after grazing from that available before grazing. This procedure was repeated over a 3year period providing a total of over 40 yield determinations in each plot.

\section{RESULTS AND DISCUSSIONS}

Annual rainfall was similar during the first and third years, averaging $1,755 \mathrm{~mm}$, but there was only $1,198 \mathrm{~mm}$ during the second year (table 2). Monthly rainfall varied from as low as $35 \mathrm{~mm}$ to as high as $378 \mathrm{~mm}$.

Hemarthria PI 299994 outyielded all the grasses, averaging 15,370 kg of dry forage/ha/yr (table 1). There were no significant differences in the productivity of Star, Coast Cross \#1 and Hemarthria PI 299995.

Cynodon plectostachyus produced much lower yields than did any of the other grasses during the second year. Apparently this grass could not tolerate the intensive management and grazing and the plots had to be excluded from the experiment during the third year due to the very poor stand.

Yields of forage consumed by the cattle in this experiment were similar to those in a nearby large scale grazing experiment (1). To make this comparison the total digestible nutrients produced/ha/yr in the large grazing experiment were calculated from the number of head carried/ha, their weight, and the weight gains made. It was assumed that $0.8 \mathrm{~kg}$ of total digestible nutrients is required daily for maintenance per $100 \mathrm{~kg}$ of liveweight and $3.53 \mathrm{~kg}$ for each $\mathrm{kg}$ of weight gain. The dry forage 
TABLE 2.-Monthly rainfall at the experiment site $(\mathrm{mm})$

\begin{tabular}{lrrr}
\hline Month & First year & Second year & Third year \\
\hline July & 74 & 35 & 165 \\
August & 178 & 96 & 315 \\
September & 183 & 131 & 103 \\
October & 201 & 378 & 98 \\
November & 273 & 57 & 295 \\
December & 280 & 90 & 49 \\
January & 97 & 122 & 35 \\
February & 119 & 20 & 68 \\
March & 130 & 49 & 128 \\
April & 145 & 98 & 276 \\
May & 78 & 80 & 89 \\
June & 35 & 42 & 95 \\
\hline Total & 1,793 & 1,198 & 1,716 \\
\hline
\end{tabular}

consumed by the grazing cattle was then calculated from these data assuming that the ingested forage was $55 \%$ digestible as indicated by the experiments summarized by Vicente-Chandler et al. $(7,8)$.

Table 1 shows that in the large grazing experiment, Star grass produced an average of $13,820 \mathrm{~kg}$ of dry forage/ha/yr compared to $12,445 \mathrm{~kg} / \mathrm{ha} / \mathrm{yr}$ in the experiment discussed in this paper. Hemarthria PI 299995 produced $12,740 \mathrm{~kg}$ of dry forage/ha/yr in the large grazing experiment compared to $13,685 \mathrm{~kg} / \mathrm{ha} / \mathrm{yr}$ in the present experiment.

There is thus reasonable agreement between forage yields produced in the large scale grazing experiment and those produced using the small enclosures and techniques described in this paper.

\section{RESUMEN}

Se determinó el forraje producido por cinco gramíneas pastadas en parcelas repetidas de $10 \times 10 \mathrm{~m}$ en un experimento de tres años en Corozal.

Hemarthria PI299994 produjo rendimientos significativamente más altos, $15,370 \mathrm{~kg}$ de forraje seco/ha y año, que los de las otras gramíneas. No hubo diferencia significativa entre la producción de las siguientes gramíneas expresada en $\mathrm{kg}$ de forraje seco/ha y año: Estrella, 12,445; Bermuda Coast Cross \#1, 12,285; Hemarthria PI 299995 , 13,685. De otro lado, la Cynodon plectostachyus no toleró el pastoreo intensivo practicado en este experimento y sólo produjo $4,695 \mathrm{~kg}$ de forraje seco/ha durante el segundo año, por lo cual se descartó el tercer año.

La producción de forraje por las yerbas Estrella y Hemarthria PI 299995 fue comparable a la obtenida en un experimento de pastoreo adyacente con parcelas de 0.4 ha. 


\section{LITERATURE CITED}

1. Caro-Costas, R., 1980. Weight gains of cows fed on five grass pastures intensively managed in the humid hill region of Puerto Rico, J. Agri. Univ. P.R. 64(1): 43-8.

2. - - Abruña, F., and Vicente-Chandler, J., 1973. Comparison of heavily fertilized pangola grass and star gxass pastures under humid tropical conditions, Agron. J., 65: $132-3$.

3. --, Vicente-Chandler, J., Abruña, F., 1965. Productivity of intensively managed pastures of 5 grasses on steep slopes in the humid mountains of Puerto Rico, J. Agri. Univ. P.R., 49(1): 99-111.

4. _- _ - _ - 1976. Comparison of heavily fertilized Congo, Star, and Pangola grass pastures in the humid mountain region of Puerto Rico, J. Agri. Univ. P.R., 60(2): 179-85.

5. Rodríguez, J. and Silva, S., 1975. Effect of two heights and three intervals of grazing on stand of heavily fertilized Star grass pastures, J. Agri. Univ. P.R., 54(3): 215-8.

6. - - Rivera, E. and Vicente-Chandler, J., 1980. Productivity of four intensively managed grass under grazing management in the humid hill region of Puerto Rico, J. Agri. Univ. P.R. 64(2): 236-40.

7. Vicente-Chandler, J., Abruña, F., Caro-Costas, R., Figarella, J., Silva, S., and Pearson, R. W., 1974. Intensive grassland management in the humid tropics of Puerto Rico, Bull. 233, Agri. Exp. Stn. Univ. P.R.

8. - - Caro-Costas, R., Pearson, R. W., Abruña, F., Figarella, J., and Silva, S., 1964. The intensive management of tropical forrages in Puerto Rico, Bull. 187, Agri. Exp. Stn. Univ. P.R.

9. - - Rodríguez, J., and Abruña, F., 1972. Effects of two heights and three intervals of grazing on the productivity of a heavily fertilized Pangola grass pasture, J. Agri. Univ. P.R. 56(2): 110-4. 